\title{
Lexical Properties Of Pu Songling Novels
}

\author{
Khasanova Shakhzoda Abdujabbor qizi \\ Lecturer, Department "Translation Studies And International \\ Journalistic", Tashkent State University Of Oriental Studies, \\ Uzbekistan
}

\author{
G OPEn ACCESS \\ The American Journal of \\ Social Science And \\ Education Innovations \\ JULY 2020 \\ Page No.: 331-335 \\ Volume-II Issue-VII \\ PUBLISHED: 30 JULY 2020 \\ www.usajournalshub.com/inde \\ x.php/tajssei \\ Copyright: Original content \\ from this work may be used \\ under the terms of the \\ Creative Commons Attribution \\ 4.0 licence.
}

\section{Abstract}

Via studying the lexicology of the Chinese language, using Pu Songling's short stories "聊斋志异 liáozhāizhìì", the level of lexical layers of the writer's spiritual experiences at that time, the socio-political experiences of that period is relevant today. Also, in this article, a comparative study of the lexical layers of the last century and the lexical layers of today is very important and relevant.

Keywords: mythological, 文言wényán, lexicology, 仰斋志异Liáozhāi zhì yì 兄长xiōngzhăng笔记bǐjì lexical layer.

\section{Introduction}

Looking at the history of ancient Chinese literature 唐朝tángcháo Tang Chao Tang period of all-round prosperity and Secu it was raised to a new level. Among them, short stories in particular have reached the highest level of development and entered its golden age. The genre of short stories is based on folklore. They consist of the genre of parables and short stories. "The Tang period (tángcháo Táng cháo) and the song songcháo cháo period have 
evolved and evolved from folk short stories to psychological short stories" $[2,3]$.

\section{Main Part}

"Chinese novels of the eighth and fourteenth centuries are markedly different from the novels of European literature in terms of subject matter and ideology. Therefore, the definition of "highly realistic" cannot be applied to Pu Songling's short stories. It's hard to call them "fantastic." In our opinion, the definition of "magic" is more appropriate for them. In the name of Pu Songling's collections, it can be concluded that his works are in harmony with magical tales and mythological sources of the III-VI centuries" $[2,5]$.

$\mathrm{Pu}$ Songling蒲松龄púsōnglíng is one of the novelists who raised the genre of short stories in the history of Chinese literature and brought it to the next level of development. "There is relatively little biographical information about the author. From his works we can get some idea of the hard life of the artist" [8].

Using all his scientific, literary, and philological knowledge and rich life experience, the author has created a collection of short stories, The Extraordinary Tales of Liao Zhai, which has a great deal of information. Thanks to this collection of short stories ("Liao Zhai's Extraordinary Tales"), Pu Songling became famous in his homeland and later around the world" $[3,127]$.

Through translation, we can gain insight into the customs, cultures, lifestyles, and social lives of many people. About this great translator scholar G. Salomov said: "Through the translation nations interacted with each other, scholars thought with each other, and writers interacted with each other. At all times, whether it is the translation of literary, scientific or political books, the culture, science, literature and art that the people have created or are creating have only benefited from it" $[1,16]$, - he said.

"In China in the 17th century along with the story and the novel, the literary novella in Wenyang 文言 continued to develop, reaching its highest development in the work of $\mathrm{Pu}$ Songling, the author of the collection Description of the Amazing from Liao's Cabinet (Liao Zhai Zhi Yi)." [4, 713].

We know that language does not stand still, and the lexical layer of our language changes over time. Some words may lose their lexical meaning over time or become obsolete. It was observed by the lexicon of the novelist Pu Songling's "聊斋志异 Liáozhāi 
zhì yì" from the novella "僧 擘Sēng niè" [5, 22] "Sinful monk" [2, 30].

1. Lexical meanings of the word僧Sēng $[6,773]$ a word belonging to the word group noun means monk. Nowadays it is very common in the form of 僧人sēngrén. Used alone at the time of writing.

"鬼魂跟着阴曹地府的差役悠悠地来到阎王面前" [6, 22]。

(Guihhún gēnzhe yīncáo difǔ de chāiyì yōuyōu de lái dào yánwáng miànqián.)

"The ambassador of the afterlife has come to take his soul to the ruler of hell" [6, 31].

2. Focus on阴曹地府yīncáo dîfǔ:

阴yīn means dark, shadow (meaning a woman in Chinese mythology).

曹cáo has lost its lexical meaning and is now used only as a surname.

The literal meaning of 地府difŭ is hell. But this term is not used today. The phrase is one of the few words that is rarely used today. Instead of阴曹地府yīncáo dìfŭ, 阴间yīnjiān $[6,1089]$ - the ruler of hell is used. The phrase阴曹地府yīncáo difǔ is used 4 times in this novella "Sinful Monk".

3. 差役 chāiyì means servant, translated as ambassador in the text. 差役 chāiyì is used 8 times in the novel we are considering.

4. 狱yù literally means prison. The word has not lost its lexical meaning even today. It has been used 3 times in the text.

“张某过去一看, 原来是他的兄长" [5, 22]。

(Zhāng mǒu guòqù yī kàn, yuánlái shì tā de xiōngzhăng.)

"Zhang Mou looked up and saw that the monk was his brother" [2, 30].

5. 兄长xiōngzhăng $[6,1024]$ is a common word in literary language, when used alone it means big brother, and when used together it means respectful friend. In the novel The Sinful Monk, 兄长xiōngzhăng is used 11 times.

"最后, 张某跟着差役来到一个地方, 看见一个和尚大腿上穿了一条绳子, 头朝下挂在那里, 又喊又 叫, 像是要疼死了" $[5,22]$ 。

(Zuihòu, zhāng mǒu gēnzhe chāiyì lái dào yīgè dīfāng, kànjiàn yīgè héshàng dàtuǐ shàng chuānle yītiáo shéngzi, tóu cháo xià guà zài nàlǐ, yòu hăn yòu jiào, xiàng shì yào 
téng šle.)

"In the end, Zhan went with the ambassador. There he saw a monk's body wrapped in a rope and his legs hanging from the sky. She was screaming, she was dying of pain" $[3,32]$.

6. The word和尚 héshàng is used 4 times in the novel, literally meaning bonza, the priest of Buddhism.

"In particular, articles on the study of Chinese lexicology began in the second half of the twentieth century," writes Gorelov [7, 8] in his book "Lexicology of the Chinese language." Indeed, the interest in language dates back to the beginning of the last century and today the perfect study of the language in every field is the demand of today. Because how Pu Songling's "聊斋志异" novels, written at least 300 years ago, were written, depends on the lexical layers of the writer's spiritual experiences at that time. Bringing the socio-political experiences of that period to the present day is a topical issue.

Conclusion. Today, it is our goal and task to pass on the literary heritage of the past centuries to the younger generation, as well as to pass on to future generations the unique works of this literary scholar in the art of history by studying the genre of novels of the past centuries. V.M. Alekseyev also describes Pu Songling as "grammatically perfect in Chinese, taking the language out of a certain 'state shell' and introducing it to the population" [8]. In fact, it can be seen in the works of the writer. The笔记bijji ${ }^{1}$ method used in novels, the parables used 300 years ago, and the in-depth study of the lexical layer in them are very important today.

\section{References}

1. Salomov G '. Fundamentals of translation theory. -T .: Teacher 1983.

2. Ziyamuhamedov Jasur, Shamshiyeva Zebo. Liao zhai (Pu Sung ling) Novellalari (chrestomathy). - T: 2012.

3. Khasanova Shahzoda. Translation of Pu Songling's short stories. // Young translator (Collection V) - T .: TDSHU, 2020. 
4. Nepomnin O.E. The history of China from ancient times to the beginning of the 21st century. - Moscow: Science - Oriental Literature 2014.

5. 清 蒲松龄。聊斋志异。1640年 -1715 年。

6. 汉饿词典。商务印书馆出版。 - 北京： 2008, 页- 773.

7. Gorelov V.I. Lexicology of the Chinese language. - M .: Education, 1984.

8. Royallib.ru Alekseev V.M. 